\title{
15
}

\section{World War II in Kiribati}

\section{Sam Highland}

World War II in Kiribati was confined mainly to the important government bases in Banaba, Tarawa, Abemama, and Butaritari. This paper is about the Tarawa campaign, one of the bloodiest battlegrounds in the entire war, and its impact on the Kiribati people, particularly the inhabitants of Betio village, which was the stage of the main conflict between the Japanese and the Americans.

Betio is an islet and village located at the southwestern extremity of Tarawa Atoll. Until the ravages of the war, the Betio people engaged in a subsistence lifestyle with some affluence. The land abounded with tropical fruits and crops, mainly coconuts, breadfruit, pumpkins, sweet potatoes, pandanus, papaya, and traditional root crops. The surrounding sea teemed with marine life, fish, and molluscs, readily available all year round. Life was easy, luxurious, and enjoyable before the threat of war came in the first week of December 1941. The population of Betio in 1941 was about four hundred, including a few expatriates.

\section{The Japanese Invasion of Tarawa Atoll}

The Japanese landed on the ocean side of the southwestern part of Betio at about 3 A.M. when the village was asleep. All the expatriates were captured, interrogated, and threatened unless they responded accurately to the demands of the Japanese. Everybody was rounded up near the post office, and some of the captives were tied up with ropes to coconut trees. The only food store on Betio, that of Burns Philp, was taken over by the Japanese and later destroyed. The

A longer version of this chapter was published in Remembering the Pacific War, ed. by Geoff White (Honolulu: Center for Pacific Island Studies, 1991), 109-112. 
Betio villagers had depended on the Burns Philp store for their basic needs other than traditional food. Curfews were set, and most movements were restricted. At about 4 P.M. that same day, when everyone had been gathered at the post office, the Japanese flag was hoisted and the Japanese commander declared Tarawa to be under Japanese jurisdiction. The Japanese left Tarawa that same day, leaving behind the Betio people, who were scared and worried about their lands and lives. They could do nothing to escape a war they had nothing to do with. They were confused, distressed, and totally lost.

Early in 1942 the Japanese returned to Tarawa. When they landed again on Betio, the villagers expected more calamity. This came true when the Japanese destroyed all sailing and fishing canoes to prevent the people from escaping. Crops such as babai taro (a prestigious root crop) and coconut trees were cut down and buried. Local houses and government staff quarters were destroyed. The whole islet was cleared of trees and houses in the first few weeks to make way for Japanese fortifications. People were forced to provide free labor and at times their personal belongings, such as clothing, were taken by the Japanese for their own use. Following several weeks of hard labor, the local people were forced to leave their home village and find shelter in North Tarawa where the majority had no lands to stay on. As war refugees they had to depend on the goodwill and generosity of others for their maintenance. The move to North Tarawa was made more difficult because of the destruction of canoes. The Betio villagers had to walk and navigate the 25 -mile stretch of reefs and tidal passages, laden with whatever personal belongings they could carry. They believed it was the end of the world for them.

Once the Betio people were evacuated, the Japanese recruited the men for hard labor to complete the fortification of the tiny islet-the construction of war bunkers, the laying of concrete structures crowned with sharpened metal on the reef around the islet, the construction of the airstrip, which covered almost a quarter of Betio, and the Japanese quarters. As most of the traditional crops had been destroyed, the laborers had to find extra food for themselves.

A popular punishment for failure to carry out orders was to tie up a worker with ropes and place a stick of dynamite between his legs. Another was flogging. Two locals, both mental patients, were shot and killed by the Japanese for refusing to carry out orders. With these cruel and inhuman treatments, the Japanese exploited the gentle character of the Tarawa people. 
During those days of hard labor, American bombers used to raid the islet of Betio. Usually occurring during the full moon when visibility was better, the raids caused great suffering. Where could the people hide from the shelling? The usual place became the hollows of the taro pits! Two I-Kiribati lost their lives during these raids.

\section{The Arrival of the Americans}

The Americans finally landed on November 20, 1943. After seventy-seven hours of bitter fighting, the Americans recaptured Tarawa from the Japanese. The British and American flags replaced the "flag of Nippon."

A day after the Japanese surrendered, the Americans recruited over one hundred I-Kiribati to clear dead bodies and war debris on Tarawa. This time the local people experienced better working conditions. Heavy equipment was used, rations were issued in abundance, and those who were selected to work even earned wages. Free clothing was provided, and each laborer was paid about U.S. \$2 per day. The Americans established good relationships with the I-Kiribati, providing almost everything for their personal needs. Forced labor as experienced with the Japanese had ended. The Betio people's experience during the American occupation was the opposite of what was experienced under the Japanese.

During the American and British joint administration, a Labor Corps was set up. People were recruited not only from Tarawa but from the rest of the islands as well. The main tasks of this Labor Corps were to clear the island of Tarawa and to reestablish the administration of this group of islands. Two companies from the Labor Corps were sent to the Solomon Islands to do similar work. Betio's traditional way of life was gradually restored, but with great difficulty because of the extensive war damage. When the Betio villagers returned to their islet they were unable to enjoy again the prewar subsistence lifestyle they had known because the islet had been ruined by the war. More corpses and war debris were evident than crops and trees on the tiny isle, which is about three miles long and a quarter-mile wide. The rehabilitation process was not easy. Lands Commissioner Harry Maude estimated that about 17,000 coconut trees had been destroyed on Betio to make way for the airstrip and that about 14,000 square feet of taro pits were buried on Betio alone. Maude calculated that the financial compensation due the Betio land- 
owners for their loss of traditional crops was $£ 42,600$. Note that these figures relate to the Betio damage alone and do not include the cost of damage to Butaritari, Abemama, Banaba, and other parts of Tarawa (Bairiki and North Tarawa). The rich inshore fisheries of Betio were destroyed and contaminated by the war. Local fish traps were destroyed and fishing activities were disrupted for several decades. The lagoon and ocean areas were full of wreckage. Unexploded bombs and war debris of various descriptions made the marine life inedible. Instead, the Betio people had to depend on expensive, imported tinned foodstuffs for their survival.

\section{The Effects of World War II on Tarawa}

The war made a tremendous impact on the life and culture of the Betio people. It became clear to them that their splendid and serene isolation could not escape the ripples of international conflicts such as World War II. The Betio people never regained their traditional subsistence lifestyle. The ecological damage on the fragile atoll was so extensive and lasting that both land and marine productivity were affected severely. The people had to start life all over again. Taro pits took three years to develop before a crop could be harvested. Building materials had to be brought in across the lagoon from North Tarawa for the villagers to build their local dwellings. Countless material and psychological losses were sustained by the people of Betio. The restoration of the past is impossible, of course, but the development of their future appears also to have been set back by the impact of the war. The Betio people have struggled to remain a viable community against history and time. The lack of war reparations from the colonial administration and the urbanization process since the war have exacerbated the economic and social situation of the once happy and cohesive community of Betio. 